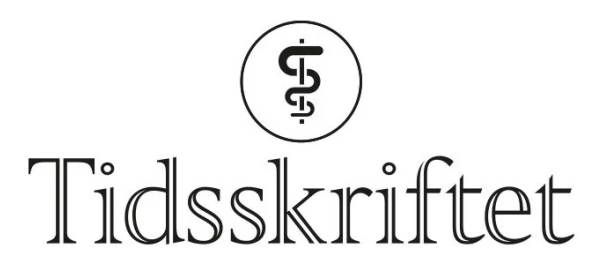

DEN NORSKE LEGEFORENING

\title{
Sylvi Johanne Aanderud
}

\author{
MINNEORD \\ EYSTEIN S. HUSEBYE \\ BJøRN GUNNAR NEDREB $\varnothing$
}

ROLF JORDE

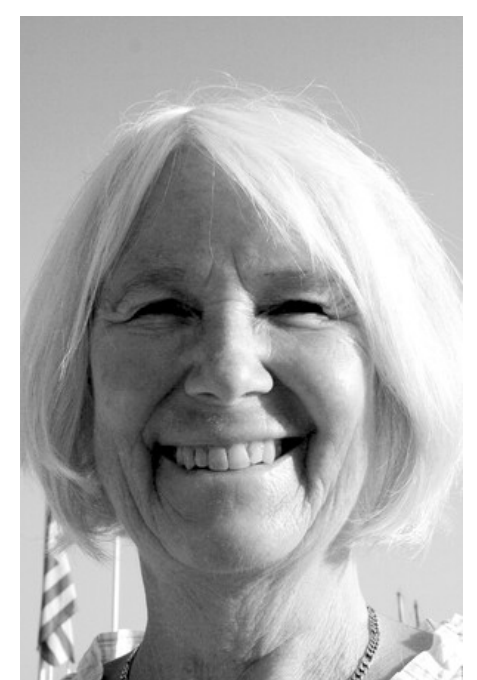

Med dyp sorg mottok vi budskapet om at Sylvi Johanne Aanderud døde 4. august 2021. Som Norges første kvinnelige professor i endokrinologi var hun et forbilde for en hel generasjon endokrinologer.

Sylvi vokste opp på Askøy og viste tidlig at hun både hadde et godt hode og flittige hender. Etter medisinstudier i Oslo og Bergen dro hun i 1968 til Hammerfest og Tromsø sammen med sin livsledsager Leif for turnustjeneste, og var assistentlege ved nevrologisk og nevrokirurgisk avdeling på Haukeland sykehus før hun fant sitt fag: indremedisin. Under spesialiseringen fattet hun interesse for endokrinologi og begynte etter hvert med eksperimentell forskning, først på Biokjemisk institutt i Bergen, deretter på Farmakologisk avdeling i Troms $\emptyset$. Hun ble i 1981 den første overlege i endokrinologi ved Regionsykehuset i Tromsø. Der var hun en drivkraft ikke bare i oppbyggingen av endokrinologisk seksjon, men også som nytenkende inspirator for hele avdelingen. 
I 1984 vendte hun tilbake til Bergen som overlege ved endokrinologisk seksjon. Hun disputerte på avhandlingen Drug influences on the extrathyroidal metabolism of thyroid hormones. A clinical and experimental study i 1988, og to år senere ble hun professor ved Universitetet i Bergen. De neste 20 årene viet hun til å bygge opp en akademisk avdeling for endokrinologi i byen.

Sylvi har hatt svært stor betydning for norsk endokrinologi, ikke minst som forbilde for yngre endokrinologer, kanskje spesielt de kvinnelige, der hun viste vei som forsker og kliniker. Hun underviste en hel generasjon medisinstudenter og utdannet mange av endokrinologene som nå arbeider på Vestlandet.

Hun var svært kunnskapsrik, men også praktisk og arbeidsom. Under hennes ledelse ble miljøet i Bergen et av de største og ledende i Norge. Sylvi var den fødte leder: intelligent, varm og flink til å inkludere alle yrkesgrupper i pasientarbeidet. Hun kunne også være hard i klypa og slamre med dørene når det var nødvendig - alltid med saklige argumenter.

Men det var mye mer i Sylvis liv enn hormoner. Hun og Leif fikk tre barn og syv barnebarn. Også i familien var hun et naturlig midtpunkt. Seiling og reiser med venner var en stor del av hennes liv.

Vi vil takke Sylvi for den læremesteren hun var og hennes store bidrag til norsk endokrinologi på mange arenaer. Vi har mistet en god leder, læremester og venn. Vi lyser fred over Sylvi Johanne Aanderuds minne.

På vegne av det endokrinologiske miljøet $i$ Norge.

Publisert: 27. september 2021. Tidsskr Nor Legeforen. DOI: 10.4045/tidsskr.21.0591

(C) Tidsskrift for Den norske legeforening 2023. Lastet ned fra tidsskriftet.no 26. april 2023. 